\title{
Microbiological and Physicochemical Quality of Irradiated Ground Beef as Affected by Added Garlic or Onion
}

\author{
Catherine W. Rico, Gui-Ran Kim, Cheorun Jo ${ }^{1}$, Ki-Chang Nam², Ho-Jin Kang ${ }^{3}$, \\ Dong-Uk Ahn ${ }^{3}$, and Joong-Ho Kwon* \\ Department of Food Science and Technology, Kyungpook National University, Daegu 702-701, Korea \\ ${ }^{I}$ Major of Animal Science and Biotechnology, Chungnam National University, Daejeon 305-764, Korea \\ ${ }^{2}$ Department of Animal Science and Technology, Sunchon National University, Suncheon 540-742, Korea \\ ${ }^{3}$ Department of Animal Science, Iowa State University, Ames, IA 50010-3150, USA
}

\begin{abstract}
The effects of garlic and onion on the microbiological and physicochemical properties of irradiated ground beef patties were evaluated. Ground beef was mixed with $0.5 \%(\mathrm{w} / \mathrm{w})$ minced garlic or $2.5 \%(\mathrm{w} / \mathrm{w})$ minced onion, vacuum-packed in oxygen-impermeable nylon/PE bags and then electron beam-irradiated at $2.5 \mathrm{kGy}$. All samples were kept at $4^{\circ} \mathrm{C}$ for $8 \mathrm{~d}$. Irradiation resulted in a $2-\log \mathrm{CFU} / \mathrm{g}$ reduction in both aerobic and coliform bacteria. The microbial counts gradually increased during storage, but those in beef that contained garlic or onion were 1-log CFU/g lower than those of the control samples after $8 \mathrm{~d}$ of storage. The $\mathrm{pH}$ value decreased during storage in all meat samples, but this decrease was greater in non-irradiated beef than in irradiated beef. The lipid oxidation, volatile basic nitrogen content and Hunter color values of raw patties were generally not affected by irradiation or the addition of garlic and onion. Sensory evaluation of cooked patties showed that the off-odor was less pronounced in samples that contained added garlic or onion than in control samples, and that the overall acceptability of beef formulated with garlic was the highest. Overall, the results of this study indicate that the addition of garlic or onion in combination with irradiation treatment enhanced the microbial quality and improved the sensory quality of irradiated ground beef.
\end{abstract}

Key words: ground beef, garlic, onion, irradiation, quality

\section{Introduction}

Irradiation is an effective intervention technology in eliminating microorganisms, especially foodborne pathogens, in fresh meat (Borsa et al., 2004; Dickson, 2005; Spoto et al., 2000; Thayer and Boyd, 1993). Because of the increasing foodborne disease caused by undercooked meats, application of ionizing radiation on raw red meat has been approved in at least 12 countries at an irradiation dose range of 2 to $8 \mathrm{kGy}$ (IAEA, 2006). However, irradiation has been reported to promote lipid oxidation, color changes, and produce undesirable flavor and off-odor in meat (Ahn et al., 2000b; Millar et al., 2000; Montgomery et al., 2003). Addition of natural food seasonings, such as ginseng and garlic herbs, on beef steaks prior to irradiation was found to inhibit lipid oxidation and minimize

*Corresponding author : Joong-Ho Kwon, Department of Food Science and Technology, Kyungpook National University, Daegu 702-701, Korea. Tel: 82-53-950-5775, Fax: 82-53-9506772, E-mail: jhkwon@knu.ac.kr surface discoloration on irradiated meat (Wong and Kitts, 2002). Moreover, they also improved the microbial safety and enhanced the flavor of the meat (Lipsky, 2000).

Garlic and onion as food ingredients are known for their biological and pharmacological properties (CorzoMartinez et al., 2007). Due to their high antimicrobial activities, both garlic and onion can be used as natural preservatives to control microbial growth in various food products (Pszczola, 2002). Previous studies on the addition of garlic in ground beef revealed that it could minimize lipid oxidation and enhance the color and microbial safety of the meat (Aydin et al., 2007; Gupta and Ravishankar, 2005; Yin and Cheng, 2003). The effect of irradiation on fresh meat has been studied extensively. However, there are limited studies on the combined effect of low dose irradiation, and addition of garlic and onion on the overall quality of meat. The objective of this study was to evaluate the effects of garlic and onion on the microbiological and physicochemical quality of ground beef patties irradiated with electron beam. 


\section{Materials and Methods}

\section{Sample preparation, irradiation, and storage}

Fresh ground beef was purchased from three local supermarkets in Daegu, Korea. Each of the ground beef sample was divided into three portions and added with one of the following treatments: $0.5 \%(\mathrm{w} / \mathrm{w})$ minced garlic, $2.5 \%(\mathrm{w} / \mathrm{w})$ minced onion, or nothing (control). The tested concentrations of garlic and onion used were selected on the basis of our preliminary study on the sensory quality of ground beef added with garlic or onion. Approximately $30 \mathrm{~g}$ of patty $(1.3 \pm 0.3 \mathrm{~cm}$ thickness $)$ was prepared and vacuum-packaged in oxygen-impermeable nylon/PE bags using a vacuum packing machine (Leepack, Bucheon, Korea). Irradiation was carried out using an electron beam accelerator with an acceleration voltage of $2.5 \mathrm{MeV}$ (EB Tech, Daejeon, Korea) at a dose of $2.5 \mathrm{kGy}$. All samples were stored at $4^{\circ} \mathrm{C}$. Analyses were conducted immediately after irradiation and after 4 and $8 \mathrm{~d}$ of storage. Triplicate experiments were conducted for sample preparation, irradiation, and storage.

\section{Microbiological analysis}

Five grams of meat were mixed with $45 \mathrm{~mL}$ sterile peptone water. Subsequent dilutions were prepared, and 1 $\mathrm{mL}$ was plated in 3M Petrifim Aerobic Plate Count (Minnesota, USA) and 3M Petrifilm Coliform Count Plate (Minnesota, USA) for total aerobic bacteria and coliform counts, respectively.

\section{Determination of Hunter's color values}

The Hunter color L- (lightness), a- (redness), and b(yellowness) values were determined using a Colorimeter (Minolta CR-200, Osaka, Japan). Measurements were taken at four random locations from both sides of the patties and the averages were reported. The L-, a-, and b-values of the standard plate were 97.66, -0.36 and 1.92, respectively.

\section{Chemical analysis}

Three grams of beef sample were mixed with $30 \mathrm{~mL}$ distilled water. The mixture was filtered (Whatman No. 41) and the $\mathrm{pH}$ of the filtrate was measured, using a $\mathrm{pH}$ meter (Thermo Scientific Orion Star Series, USA). Lipid oxidation was determined by the 2-thiobarbituric acid reactive substances (TBARS) value using the method described by Nam et al. (2001). The volatile basic nitrogen $(\mathrm{VBN})$ content was analyzed using Conway method as described by Lim et al. (1997).

\section{Sensory evaluation}

Beef patties were cooked following the method of Murano et al. (1998). The cooked beef patties were evaluated for color, aroma, off-odor, flavor, juiciness, tenderness, and overall acceptability by 10 sensory panelists. A line scale (numerical value of 5 units) was used with descriptive anchors (none and high) at each end of the line.

\section{Statistical analysis}

The results from the measurements were statistically analyzed using the Statistical Analysis System for Windows V8. Analysis of Variance and Duncan's Multiple Range Test were used at $p<0.05$, and the mean values and standard error of the means (SEM) were reported.

\section{Results and Discussion}

\section{Microbiological quality}

Irradiation resulted in a 2-log CFU/g reduction in total aerobic bacteria in all samples (Table 1). Addition of garlic or onion did not have a direct effect on the number of total aerobic bacteria in beef patties, but after $8 \mathrm{~d}$ of storage at $4^{\circ} \mathrm{C}$, the number of total aerobic bacteria in beef formulated with garlic and onion were 1-log CFU/g lower than that of the control ones. Similarly, coliform counts decreased by 1-2 logs CFU/g after irradiation. The counts gradually increased during storage, but the increase was greater in control beef than in garlic- or onion-added beef patties. Wong and Kitts (2002) also observed a slight reduction in the bacterial counts of both irradiated (2-4 $\mathrm{kGy}$ ) and non-irradiated beef steaks pre-seasoned with $1 \%$ garlic after 2 weeks of refrigerated storage. This was mainly due to the synergistic antimicrobial effect between garlic and electron beam irradiation. Garlic and onion contain high organic sulfur compounds that are responsible for their antibacterial properties (Corzo-Martinez et al., 2007). In our study, the minimal antimicrobial effect of garlic and onion in ground beef patties may be due to low concentrations of garlic $(0.5 \%)$ and onion $(2.5 \%)$ added in beef patties. However, our preliminary study indicated that higher concentrations of garlic and onion resulted in reduced sensory quality of meat (data not shown in a tabular form). Aydin et al. (2007) reported that chopped garlic inhibited the microbial growth in ground beef depending on the garlic concentration, but the effect was still minimal even at the highest concentration (10\%).

\section{Hunter's color values}

The Hunter's L-values were not significantly affected 
Table 1. Microbial counts in irradiated ground beef patties added with minced garlic or onion stored at $4^{\circ} \mathrm{C}$ for $8 \mathrm{~d}$

\begin{tabular}{cccccccc}
\hline \hline \multirow{2}{*}{ Microorganism } & \multirow{2}{*}{$\begin{array}{c}\text { Storage time } \\
\text { (day) }\end{array}$} & \multicolumn{2}{c}{ Control beef } & \multicolumn{2}{c}{$\begin{array}{c}\text { Beef formulated with garlic } \\
(0.5 \%)\end{array}$} & \multicolumn{2}{c}{$\begin{array}{c}\text { Beef formulated with onion } \\
(2.5 \%)\end{array}$} \\
\cline { 3 - 8 } & & $0 \mathrm{kGy}$ & $2.5 \mathrm{kGy}$ & $0 \mathrm{kGy}$ & $2.5 \mathrm{kGy}$ & $0 \mathrm{kGy}$ & $2.5 \mathrm{kGy}$ \\
\hline Total aerobic & 0 & $8.9 \times 10^{6}$ & $4.1 \times 10^{4}$ & $5.5 \times 10^{6}$ & $8.7 \times 10^{4}$ & $2.2 \times 10^{6}$ & $3.5 \times 10^{4}$ \\
bacteria & 4 & $2.8 \times 10^{6}$ & $3.0 \times 10^{4}$ & $9.8 \times 10^{5}$ & $7.8 \times 10^{4}$ & $3.8 \times 10^{5}$ & $3.0 \times 10^{4}$ \\
$(\text { CFU/g) })^{1)}$ & 8 & $3.1 \times 10^{6}$ & $4.4 \times 10^{6}$ & $5.9 \times 10^{5}$ & $1.7 \times 10^{5}$ & $2.3 \times 10^{5}$ & $2.8 \times 10^{4}$ \\
\hline Coliform & 0 & $5.4 \times 10^{3}$ & $2.8 \times 10^{1}$ & $4.2 \times 10^{3}$ & $4.1 \times 10^{1}$ & $8.9 \times 10^{2}$ & $1.0 \times 10^{1}$ \\
bacteria & 4 & $2.5 \times 10^{4}$ & $5.5 \times 10^{2}$ & $7.4 \times 10^{3}$ & $8.1 \times 10^{2}$ & $2.6 \times 10^{3}$ & $7.1 \times 10^{1}$ \\
$(\text { CFU/g) })^{1)}$ & 8 & $1.6 \times 10^{5}$ & $2.1 \times 10^{3}$ & $2.4 \times 10^{4}$ & $1.1 \times 10^{3}$ & $4.6 \times 10^{3}$ & $2.0 \times 10^{2}$ \\
\hline
\end{tabular}

1) Values are means of three replications.

Table 2. Hunter color values of irradiated ground beef patties added with minced garlic or onion stored at $4^{\circ} \mathrm{C}$ for $8 \mathrm{~d}$

\begin{tabular}{|c|c|c|c|c|c|c|c|c|}
\hline & \multirow{2}{*}{$\begin{array}{l}\text { Storage time } \\
\quad \text { (day) }\end{array}$} & \multicolumn{2}{|c|}{ Control beef } & \multicolumn{2}{|c|}{$\begin{array}{l}\text { Beef formulated with garlic } \\
\qquad(0.5 \%)\end{array}$} & \multicolumn{2}{|c|}{$\begin{array}{l}\text { Beef formulated with onion } \\
\qquad(2.5 \%)\end{array}$} & \multirow[t]{2}{*}{$\mathrm{SEM}^{2)}$} \\
\hline & & $0 \mathrm{kGy}$ & $2.5 \mathrm{kGy}$ & $0 \mathrm{kGy}$ & $2.5 \mathrm{kGy}$ & $0 \mathrm{kGy}$ & $2.5 \mathrm{kGy}$ & \\
\hline \multirow{3}{*}{$\mathrm{L}^{1)}$} & 0 & $48.78^{\mathrm{aA}}$ & $48.31^{\mathrm{aA}}$ & $48.99^{\mathrm{aA}}$ & $46.20^{\mathrm{aA}}$ & $47.27^{\mathrm{aA}}$ & $45.97^{\mathrm{aA}}$ & 1.03 \\
\hline & 4 & $50.33^{\mathrm{aA}}$ & $47.66^{\mathrm{aA}}$ & $50.70^{\mathrm{aA}}$ & $46.77^{\mathrm{aA}}$ & $48.30^{\mathrm{aA}}$ & $47.74^{\mathrm{aA}}$ & 1.19 \\
\hline & 8 & $49.39^{\mathrm{aA}}$ & $47.67^{\mathrm{aA}}$ & $47.48^{\mathrm{aA}}$ & $47.12^{\mathrm{aA}}$ & $47.27^{\mathrm{aA}}$ & $48.14^{\mathrm{aA}}$ & 0.91 \\
\hline & SEM & 0.76 & 0.80 & 1.07 & 1.01 & 1.08 & 1.45 & \\
\hline \multirow{3}{*}{$\mathrm{a}$} & 0 & $10.94^{\mathrm{aB}}$ & $9.44^{\mathrm{abB}}$ & $7.21^{\mathrm{bB}}$ & $9.34^{\mathrm{abB}}$ & $8.97^{\mathrm{abB}}$ & $10.49^{\mathrm{aA}}$ & 0.71 \\
\hline & 4 & $11.72^{\mathrm{abAB}}$ & $13.20^{\mathrm{abAB}}$ & $10.15^{\mathrm{bB}}$ & $13.60^{\mathrm{abAB}}$ & $16.11^{\mathrm{aA}}$ & $12.64^{\mathrm{abA}}$ & 1.40 \\
\hline & 8 & $14.85^{\mathrm{aA}}$ & $14.48^{\mathrm{aA}}$ & $17.88^{\mathrm{aA}}$ & $14.81^{\mathrm{aA}}$ & $18.13^{\mathrm{aA}}$ & $13.80^{\mathrm{aA}}$ & 1.44 \\
\hline & SEM & 1.05 & 1.20 & 1.22 & 1.41 & 0.71 & 1.61 & \\
\hline \multirow{3}{*}{$\mathrm{b}$} & 0 & $6.26^{\mathrm{bB}}$ & $6.33^{\mathrm{bA}}$ & $8.38^{\mathrm{aA}}$ & $7.52^{\mathrm{abA}}$ & $7.42^{\mathrm{abA}}$ & $6.12^{\mathrm{bA}}$ & 0.52 \\
\hline & 4 & $8.58^{\mathrm{aA}}$ & $5.74^{\mathrm{bcA}}$ & $7.78^{\mathrm{abA}}$ & $7.35^{\mathrm{abcA}}$ & $5.55^{\mathrm{cB}}$ & $6.05^{\mathrm{bcA}}$ & 0.64 \\
\hline & 8 & $7.20^{\mathrm{aAB}}$ & $6.96^{\mathrm{aA}}$ & $7.16^{\mathrm{aA}}$ & $7.81^{\mathrm{aA}}$ & $6.80^{\mathrm{aAB}}$ & $7.99^{\mathrm{aA}}$ & 0.48 \\
\hline & SEM & 0.45 & 0.40 & 0.62 & 0.61 & 0.42 & 0.72 & \\
\hline \multirow{3}{*}{$\Delta \mathrm{E}$} & 0 & 0.00 & 0.15 & 0.68 & 2.31 & 1.18 & 2.63 & \\
\hline & 4 & 1.07 & 1.59 & 1.88 & 2.69 & 1.80 & 1.39 & \\
\hline & 8 & 0.52 & 2.03 & 3.29 & 2.73 & 3.53 & 1.50 & \\
\hline
\end{tabular}

${ }^{\mathrm{a}-\mathrm{c}}$ Means in the same row with different superscripts are significantly different $(p<0.05)$.

${ }^{\text {A-B }}$ Means in the same column with different superscripts are significantly different $(p<0.05)$.

${ }^{1)}$ Hunter color parameters: L, degree of whiteness (white $+100 \rightarrow 0$ black); a, degree of redness (red $+100 \rightarrow-80$ green); b, degree of yellowness (yellow $+70 \rightarrow-80$ blue); and $\Delta E$ : overall color difference $\left(\sqrt{\Delta \mathrm{L}^{2}+\Delta \mathrm{a}^{2}+\Delta \mathrm{b}^{2}}\right)$.

${ }^{2)} \mathrm{SEM}=$ standard error of the means.

by the addition of garlic or onion, irradiation, and storage (Table 2). No significant changes in the a-values were observed in irradiated beef formulated with garlic and onion. However, the a-values of all samples increased during storage, indicating that the beef patties became redder. This is in accordance with the findings of Kim et al. (2002), in which the Hunter's a-values of beef loins in vacuum packaging increased after $7 \mathrm{~d}$ of storage regardless of irradiation treatment. The development of red color is attributed to the formation of carboxymyoglobin and reduced myoglobin in irradiated or non-irradiated beef (Millar et al., 2000). Regarding the yellowness (bvalue) of beef patties, no considerable changes were observed in irradiated beef formulated with garlic or onion even after $8 \mathrm{~d}$ of storage. The overall changes in color $(\Delta E)$ of beef patties showed that irradiation and addition of garlic or onion resulted in a noticeable color difference (Table 2). However, the magnitude of the color change during storage was higher than the total color changes resulting from irradiation and addition of garlic and onion. This indicates that prolonged storage at $4^{\circ} \mathrm{C}$ was more influential than irradiation treatment or with the addition of garlic and onion on the color changes of ground beef patties.

\section{Chemical quality}

Generally, the $\mathrm{pH}$ of the meat samples was not affected by either irradiation or addition of garlic or onion (Table 
3). However, the $\mathrm{pH}$ decreased during storage in all beef patties, and the decrease was greater in non-irradiated samples than that of the irradiated ones. This is due to the higher microbial count in non-irradiated patties. Some bacteria, particularly Gram positive bacteria, produce organic acids, which can influence the $\mathrm{pH}$ of the fresh meat (Wong and Kitts, 2002). The lipid oxidation of the beef samples was not initially influenced by either irradiation or addition of garlic and onion. Ahn et al. (2000a) reported that the use of vacuum-packaging minimized the oxidative changes in irradiated meat. The storage conditions and availability of oxygen were found to be more important for the development of lipid oxidation than irradiation. After $4 \mathrm{~d}$ of storage, the TBARS value of irradiated beef formulated with onion was significantly lower $(p<0.05)$ than that of the non-irradiated and irradiated control and garlic-added samples. A study involving the use of onion extracts in turkey breast rolls revealed that the lipid oxidation was significantly reduced in turkey rolls after $2 \mathrm{~d}$ of refrigerated storage (Tang and Cronin, 2007). Onion has high quercetin content, which is responsible for its antioxidant property. Irradiation at $2.5 \mathrm{kGy}$ did not significantly change the VBN values in beef patties. Irradiated beef formulated with onion exhibited lower VBN content than that of the irradiated control beef and garlic-added samples, but the difference disappeared during storage.

\section{Sensory evaluation}

Sensory scores for color and aroma were highest in irradiated beef formulated with garlic (Table 4). Off-odor score was highest in irradiated control beef and lowest in

Table 3. pH, TBARS, and VBN values of irradiated ground beef patties added with minced garlic or onion stored at $4^{\circ} \mathrm{C}$ for $8 \mathrm{~d}$

\begin{tabular}{|c|c|c|c|c|c|c|c|c|}
\hline \multirow[t]{2}{*}{ Parameter } & \multirow{2}{*}{$\begin{array}{l}\text { Storage time } \\
\text { (day) }\end{array}$} & \multicolumn{2}{|c|}{ Control beef } & \multicolumn{2}{|c|}{$\begin{array}{l}\text { Beef formulated with garlic } \\
\qquad(0.5 \%)\end{array}$} & \multicolumn{2}{|c|}{$\begin{array}{l}\text { Beef formulated with onion } \\
\qquad(2.5 \%)\end{array}$} & \multirow[t]{2}{*}{ SEM $^{1}$} \\
\hline & & $0 \mathrm{kGy}$ & $2.5 \mathrm{kGy}$ & $0 \mathrm{kGy}$ & $2.5 \mathrm{kGy}$ & $0 \mathrm{kGy}$ & $2.5 \mathrm{kGy}$ & \\
\hline \multirow{3}{*}{$\mathrm{pH}$} & 0 & $5.47^{\mathrm{bA}}$ & $5.48^{\mathrm{bA}}$ & $5.47^{\mathrm{bA}}$ & $5.47^{\mathrm{bA}}$ & $5.55^{\mathrm{aA}}$ & $5.48^{\mathrm{bA}}$ & 0.01 \\
\hline & 4 & $5.25^{\mathrm{bB}}$ & $5.41^{\mathrm{aA}}$ & $5.13^{\mathrm{cB}}$ & $5.37^{\mathrm{aA}}$ & $5.12^{\mathrm{cB}}$ & $5.45^{\mathrm{aA}}$ & 0.03 \\
\hline & 8 & $4.99^{\mathrm{cC}}$ & $5.27^{\mathrm{aB}}$ & $4.89^{\mathrm{dC}}$ & $5.11^{\mathrm{bB}}$ & $5.05^{\mathrm{bcB}}$ & $5.28^{\mathrm{aB}}$ & 0.03 \\
\hline \multicolumn{2}{|c|}{ SEM } & 0.04 & 0.04 & 0.12 & 0.04 & 0.10 & 0.05 & \\
\hline \multirow{3}{*}{$\begin{array}{c}\text { TBARS } \\
\text { (O.D. } 531 \mathrm{~nm})\end{array}$} & 0 & $0.40^{\mathrm{bC}}$ & $0.46^{\mathrm{abB}}$ & $0.55^{\mathrm{abA}}$ & $0.59^{\mathrm{aA}}$ & $0.38^{\mathrm{bB}}$ & $0.48^{\mathrm{abB}}$ & 0.05 \\
\hline & 4 & $0.57^{\mathrm{abB}}$ & $0.66^{\mathrm{aA}}$ & $0.63^{\mathrm{aA}}$ & $0.57^{\mathrm{abA}}$ & $0.48^{\mathrm{bB}}$ & $0.25^{\mathrm{cC}}$ & 0.03 \\
\hline & 8 & $0.92^{\mathrm{abA}}$ & $0.58^{\mathrm{bcAB}}$ & $1.03^{\mathrm{aA}}$ & $0.36^{\mathrm{cB}}$ & $0.98^{\mathrm{abA}}$ & $0.69^{\mathrm{abcA}}$ & 0.10 \\
\hline \multicolumn{2}{|c|}{ SEM } & 0.02 & 0.02 & 0.02 & 0.03 & 0.04 & 0.03 & \\
\hline \multirow{3}{*}{$\begin{array}{l}\mathrm{VBN} \\
(\%)\end{array}$} & 0 & $0.33^{\mathrm{abA}}$ & $0.35^{\mathrm{aA}}$ & $0.34^{\mathrm{abA}}$ & $0.35^{\mathrm{aAB}}$ & $0.30^{\mathrm{abA}}$ & $0.28^{\mathrm{bB}}$ & 0.02 \\
\hline & 4 & $0.33^{\mathrm{bA}}$ & $0.33^{\mathrm{bA}}$ & $0.42^{\mathrm{aA}}$ & $0.39^{\mathrm{aA}}$ & $0.33^{\mathrm{bA}}$ & $0.34^{\mathrm{bA}}$ & 0.02 \\
\hline & 8 & $0.34^{\mathrm{bA}}$ & $0.32^{\mathrm{bA}}$ & $0.42^{\mathrm{aA}}$ & $0.32^{\mathrm{bB}}$ & $0.33^{\mathrm{bA}}$ & $0.31^{\mathrm{bAB}}$ & 0.02 \\
\hline \multicolumn{2}{|c|}{ SEM } & 0.01 & 0.02 & 0.03 & 0.02 & 0.02 & 0.01 & \\
\hline
\end{tabular}

${ }^{\mathrm{a}-\mathrm{d}}$ Means in the same row with different superscripts are significantly different $(p<0.05)$.

${ }^{A-C}$ Means in the same column with different superscripts are significantly different $(p<0.05)$.

${ }^{1)}$ Standard error of the means.

Table 4. Sensory evaluation of cooked irradiated ground beef patties added with minced garlic or onion after $4 \mathrm{~d}$ of storage at $4^{\circ} \mathrm{C}$

\begin{tabular}{llllllll}
\hline \hline \multirow{2}{*}{ Parameter } & \multicolumn{2}{c}{ Control beef } & \multicolumn{2}{c}{$\begin{array}{c}\text { Beef formulated with garlic } \\
(0.5 \%)\end{array}$} & $\begin{array}{c}\text { Beef formulated with onion } \\
(2.5 \%)\end{array}$ & \multirow{2}{*}{ SEM ${ }^{1)}$} \\
\cline { 2 - 6 } & $0 \mathrm{kGy}$ & $2.5 \mathrm{kGy}$ & $0 \mathrm{kGy}$ & $2.5 \mathrm{kGy}$ & $0 \mathrm{kGy}$ & $2.5 \mathrm{kGy}$ \\
\hline Color & $4.0^{\mathrm{a}}$ & $3.2^{\mathrm{b}}$ & $3.8^{\mathrm{ab}}$ & $4.3^{\mathrm{a}}$ & $3.2^{\mathrm{b}}$ & $3.3^{\mathrm{b}}$ & 0.21 \\
Aroma & $3.4^{\mathrm{ab}}$ & $3.0^{\mathrm{b}}$ & $3.3^{\mathrm{ab}}$ & $4.1^{\mathrm{a}}$ & $3.6^{\mathrm{ab}}$ & $3.3^{\mathrm{ab}}$ & 0.28 \\
Off-odor & $3.0^{\mathrm{ab}}$ & $3.3^{\mathrm{a}}$ & $2.9^{\mathrm{abc}}$ & $1.7^{\mathrm{d}}$ & $2.0^{\mathrm{bcd}}$ & $2.1^{\mathrm{bcd}}$ & 0.32 \\
Flavor & $2.4^{\mathrm{b}}$ & $2.5^{\mathrm{b}}$ & $3.7^{\mathrm{a}}$ & $2.9^{\mathrm{ab}}$ & $3.2^{\mathrm{ab}}$ & $2.7^{\mathrm{b}}$ & 0.29 \\
Juiciness & $2.1^{\mathrm{b}}$ & $2.1^{\mathrm{b}}$ & $3.3^{\mathrm{a}}$ & $2.6^{\mathrm{ab}}$ & $2.9^{\mathrm{ab}}$ & $2.6^{\mathrm{ab}}$ & 0.26 \\
Tenderness & $3.0^{\mathrm{a}}$ & $2.8^{\mathrm{a}}$ & $3.3^{\mathrm{a}}$ & $3.3^{\mathrm{a}}$ & $3.0^{\mathrm{a}}$ & $3.1^{\mathrm{a}}$ & 0.20 \\
Overall acceptability & $3.2^{\mathrm{b}}$ & $2.8^{\mathrm{b}}$ & $3.5^{\mathrm{ab}}$ & $4.1^{\mathrm{a}}$ & $3.1^{\mathrm{b}}$ & $2.8^{\mathrm{b}}$ & 0.27 \\
\hline
\end{tabular}

\footnotetext{
${ }^{a-d}$ Means in the same row with different superscripts are significantly different $(p<0.05)$.

${ }^{1)}$ Standard error of the means.
} 
irradiated meat with garlic and onion. Studies showed that irradiation resulted in the development of off-odor in ground beef (Montgomery et al., 2003; Murano et al., 1998). Results of this study indicate that garlic and onion could minimize the irradiation off-odor in meat. The flavor and juiciness scores were highest in beef formulated with garlic (Table 4). No significant difference was observed in beef tenderness among treatments $(p<0.05)$. Irradiated beef samples with garlic had the highest overall acceptability. Addition of minced onion to beef patties did not cause significant change on the overall sensory acceptability of the cooked meat.

\section{Conclusion}

Results of this study showed that addition of garlic or onion prior to irradiation of ground beef patties could enhance the microbial quality of meat during refrigerated storage. It could also minimize the off-odor and improve the overall sensory quality of cooked patties. The Hunter's color and chemical quality of irradiated and non-irradiated beef patties were generally not affected by the addition of garlic or onion.

\section{References}

1. Ahn, D. U., Jo, C., Du, M., Olson, D. G., and Nam, K. C. (2000a) Quality characteristics of pork patties irradiated and stored in different packaging and storage conditions. Meat Sci. 56, 203-209.

2. Ahn, D. U., Jo, C., Lee, and E. J. (2000b) Analysis of volatile components and the sensory characteristics of irradiated raw pork. Meat Sci. 54, 209-215.

3. Aydin, A., Bostan, K., Erkan, M., and Bingol, B. (2007) The antimicrobial effects of chopped garlic in ground beef and raw meatball. J. Med. Food 10, 203-207.

4. Borsa, J., Lacroix, M., Ouattara, B., and Chiasson, F. (2004) Radiosensitization: enhancing the radiation inactivation of foodborne bactera. Radiat. Phys. Chem. 71, 135-139.

5. Corzo-Martinez, M., Corzo, N., and Villamiel, M. (2007) Biological properties of onions and garlic. Trends Food Sci. Technol. 18, 609-625.

6. Dickson, J. S. (2005) Irradiation of fresh meat. In: Improving the food safety of fresh meat. Sophos, J. N. (ed), Woodhead Publishing Ltd., Cornwall, England, pp. 418-432.

7. Gupta, S. and Ravishankar, S. (2005) A comparison of the antimicrobial activity of garlic, ginger, carrot, and turmeric pastes against Escherichia coli O157:H7 in laboratory buffer and ground beef. Foodborne Pathogens Dis. 2, 330-340.

8. International Atomic Energy Agency (2006) Clearance of irradiated food database. http://www.iaea.org/icgfi/data.htm. Accessed on December 5, 2006.

9. Kim, Y. H., Nam, K. C., and Ahn, D. U. (2002) Color, oxidation-reduction potential, and gas production of irradiated meats from different animal species. J. Food Sci. 67, 16921695.

10. Lim, C. Y., Lee, S. J., Lee, I. S., Kim, J. K., and Sung, N.J. (1997) The formation of N-nitrosamine during storage of salted mackerel, Scomber japonicus. J. Korean Soc. Food Sci. Nutr. 26, 45-53.

11. Lipsky, J. (2000) Spicing up the value of steak with pre-seasoning. Meat Marketing Technol. 8, 56-57.

12. Millar, S. J., Moss, B. W., and Stevenson, M.H. (2000) The effect of ionizing radiation on the colour of beef, pork, and lamb. Meat Sci. 55, 349-360.

13. Montgomery, J. L., Parrish, F. C., Olson, D. G., Dickson, J. S., and Niebuhr, S. (2003) Storage and packaging effects on sensory and color characteristics of ground beef. Meat Sci. 64, 357-363.

14. Murano, P. S., Murano, E. A., and Olson, D.G. (1998) Irradiated ground beef: sensory and quality changes during storage under various packaging conditions. J Food Sci. 63, 548551.

15. Nam, K. C., Hur, H., and Ahn, D. U. (2001) Lipid oxidation, volatiles, and color changes in irradiated raw turkey breast during frozen storage. J. Food Sci. 67, 2061-2066.

16. Pszczola, D. E. (2002) Antimicrobials: setting up additional hurdles to ensure food safety. Food Technol. 56, 99-107.

17. Spoto, M. H., Gallo, C. R., Alcarde, S. R., Gurgel, M. S., Blumer, L., Walder, J. M., and Domarco, R. E. (2000) Gamma irradiation in the control of pathogenic bacteria in refrigerated ground chicken meat. Sci. Agr. 57, 389-394.

18. Tang, X. and Cronin, D. A. (2007) The effects of brined onion extracts on lipid oxidation and sensory quality in refrigerated cooked turkey breast rolls during storage. Food Chem. 100, 712-718.

19. Thayer, D. W. and Boyd, G. (1993) Elimination of Escherichia coli $\mathrm{O} 157: \mathrm{H} 7$ in meats by gamma irradiation. Appl. Environ. Microbiol. 59, 1030-1034.

20. Wong, P. Y. and Kitts, D. D. (2002) The effects of herbal preseasoning on microbial and oxidative changes in irradiated beef steaks. Food Chem. 76, 197-205.

21. Yin, M. and Cheng, W. (2003) Antioxidant and antimicrobial effects of four garlic-derived organosulfur compounds in ground beef. Meat Sci. 63, 23-28.

$\overline{\text { (Received 2009.9.1/Revised 2009.10.26/Accepted 2009.12.2) }}$ 